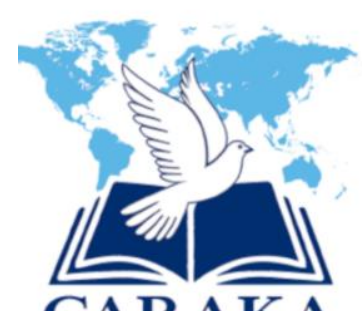

\title{
Mengembalikan Pendidikan Anak Usia Dini di Rumah Sebagai Bentuk Tanggung Jawab Orang Tua Selama Pandemi
}

\author{
Shintike Maya, Talizaro Tafonao \\ Sekolah Tinggi Teologi Real Batam \\ Shintikemaya@gmail.com \\ Talizarotafonao@gmail.com
}

\begin{abstract}
The purpose of writing this article is to see the effectiveness of learning since home-centered education during the pandemic. Before the pandemic, education at home was not an urgent matter for families, but with the presence of this covid-19, now the home has become the most appropriate place to teach Christian Religious Education repeatedly for early childhood children in learning, with various efforts and challenges faced by parents as described in this article. The method used is a qualitative descriptive method by examining the learning process at home during a pandemic. The analysis process is carried out using Bible verses in the Book of Deuteronomy and various other sources of literature such as journals, books, and other reliable reference materials related to this study. The results found by the authors that the nature of early childhood education is a concern for parents during the pandemic by looking at the concept of education in the Deuteronomy, namely parents as the main teacher / mentor, training, providing materials, examples and time. Thus, the family environment is the main environment in the formation of all aspects of early childhood life during the pandemic.
\end{abstract}

Keywords: Home, Study, Psychology, Pandemic, Kids, Parents

\begin{abstract}
Abstrak
Tujuan penulisan artikel ini adalah melihat sejauh mana keefektifan pembelajaran sejak pendidikan berpusat di rumah selama pandemi. Sebelum adanya pandemi pendidikan di dalam rumah bukan hal yang urgen bagi keluarga, tetapi dengan hadirnya covid-19 ini, kini rumah telah menjadi tempat yang paling tepat untuk orang tua mengajarkan Pendidikan Agama Kristen secara berulang-ulang bagi anakanak usia dini dalam belajar, dengan berbagai upaya dan tantangan yang dihadapi oleh orang tua sebagaimana penjelasan dalam artikel ini. Metode yang digunakan adalah metode kualitatif deskriptif dengan mengkaji proses pembelajaaran dalam rumah selama pandemi. Proses analisis yang dilakukan adalah menggunakan ayat Alkitab dalam Kitab Ulangan dan berbagai sumber literatur-literatur lain seperti jurnal, buku, dan bahan referensi lainnya yang terpercaya yang berkaitan dengan kajian tulisan ini. Hasil yang ditemukan oleh penulis bahwa hakikat pendidikan anak usia dini menjadi perhatian orang tua di masa pandemi dengan melihat konsep pendidikan dalam Ulangan, yakni orang tua sebagai pengajar, pendamping, melatih, teladan dan waktu. Keluarga menjadi tempat pertama dan lingkungan utama dalam pembentukan segala aspek kehidupan anak usia dini di masa pandemi.
\end{abstract}

Kata kunci: Rumah, Belajar, Psikologi, Pandemi, Anak, Orang tua 


\section{PENDAHULUAN}

Tulisan ini berupaya menjelaskan konsep pembelajaran anak usia dini di rumah selama pandemi. Pada dasarnya pendidikan merupakan suatu kebutuhan dasar dalam kehidupan setiap manusia. Pendidikan ini juga dapat memainkan peran penting dalam sejarah kehidupan manusia, demikian pula pendidikan yang tersirat di dalam Alkitab berperan penting dalam sejarah kehidupan kekristenan. Alkitab menjadi pusat pendidikan Kristen, yang memberi banyak pelajaran berharga mengenai kehidupan, pendidikan, ibadah dan pengalaman bersama dengan Tuhan. ${ }^{1}$ Pendidikan harus dimulai dari sejak usia dini, dimana orang yang paling dekat dan paling sering berinteraksi dengan anak usia dini yang akan berpengaruh terhadap tumbuh kembang dan pengertian anak. ${ }^{2}$ Seharusnya pendidikan dimulai dari rumah dan dilakukan oleh orang tua untuk memberikan pengertian yang benar tentang kehidupan, keluarga bahkan pengenalan akan Tuhan. ${ }^{3}$

Seiring dengan berkembangnya Ilmu Pengetahuan dan Tekhnologi, orang tua dituntut untuk mengimbangi perkembangan tersebut tetapi dalam perjalanannya orang tua lebih sibuk dengan pekerjaan daripada memperhatikan pendidikan anak-anaknya sehingga banyak orang tua menyerahkan tugas pendidikan kepada pihak sekolah, pengasuh, tempat penitipan anak bahkan kepada gereja (Sekolah Minggu). Dalam kajian yang dilakukan oleh Manurung dan Tafonao mengatakan bahwa selama pembelajaran online ini masih ada orang tua yang menyerahakan anak-anak kepada pembantu, pengasuh dan guru les. ${ }^{4}$ Menurut hemat penulis bahwa apa yang dilakukan oleh orang tua di atas tidak ada yang salah tetapi yang menjadi masalah adalah bila pendidikan dalam keluarga tidak berfungsi sebagaimana yang diperintahkan oleh Tuhan di dalam Kitab Ulangan.

Sejak Bapak Presiden Joko Widodo mengumumkan tentang corona virus yang telah masuk di Indoensia dan sejak itu juga semua aktifitas baik tentang beribadah, bekerja bahkan kegitan belajar di sekolah, semua di pusatkan di rumah. ${ }^{5}$ Situasi ini juga berdampak bagi pendidikan anak usia dini (PAUD), anak-anak tidak dapat lagi datang ke sekolah untuk bertemu dengan guru dan teman-teman untuk bermain seperti biasa, selain orang tua tidak

\footnotetext{
${ }^{1}$ Tety Tety and Soeparwata Wiraatmadja, "Prinsip-Prinsip Filsafat Pendidikan Kristen," Evangelikal: Jurnal Teologi Injili dan Pembinaan Warga Jemaat 1, no. 1 (2017): 65.

${ }^{2}$ Yuliani Nurani, Perspektif Baru Konsep Dasar Pendidikan Anak Usia Dini (Jakarta: CV. Campustaka, 2019): 264.

${ }^{3}$ Handreas Hartono, “Membentuk Karakter Kristen Pada Anak Keluarga Kristen,” Kurios 2, no. 1 (2018): 62-100.

${ }^{4}$ Rismag Dalena Florentina Monika Br Manurung and Talizaro Tafonao, "Problem Pembelajaran Online Di Masa Pandemi Terhadap Psikologi Anak Usia 10-12 Tahun,” Mathetheou: Religios Studies 1, no. 1 (2021): 25.

5 “Https://Nasional.Kompas.Com/Read/2020/03/02/11265921/Breaking-News-Jokowi-Umumkan-DuaOrang-Di-Indonesia-Positif-Corona."
}

205 | Copyright@ 2021, CARAKA, ISSN 2722-1407 (Cetak), 2722-1393 (Online) 
memiliki Handphone android dan laptop, keterbatasan ekonomi keluarga dalam pembelian paket data internet, jaringan internet yang masih belum merata. ${ }^{6}$ Menurut hemat penulis bahwa situasi ini dapat menjadi suatu momentum bagi orang tua bahwa betapa pentingnya tanggung jawab orang tua dalam mendidik anak di rumah, karena itu yang dipesankan oleh Allah kepada bangsa Israel (orang tua) untuk mendidik anak-anaknya sebagaimana tertuang dalam Kitab Ul. 6:6-7. Menurut Hairuddin, ada tiga hal penting yang diperhatikan oleh orang tua dalam mendidk anak di rumah, yaitu pemberian nutrisi fisik, nutrisi rohani dan pendidikan. ${ }^{7}$ Dengan melihat problem yang terjadi saat ini (Covid-19), maka dalam penelitian Mufazian dan Fauziah mengamati bahwa, salah satu kunci utama dalam mendidik anak usia dini di masa pandemi adalah kecakapan dari orang tua. ${ }^{8}$ Tetapi ada kendala lain dalam mendampingi anak di masa pandemi menurut Wardani dan Ayriza, yakni orang tua masih kurang memahami berbagai materi pembelajaran serta kesulitan dalam menumbuhkan minat belajar anak dan tidak memiliki cukup waktu untuk mendampingi anak karena harus bekerja. ${ }^{9}$ Pada dasarnya jika dipahami dengan seksama bahwa pendidikan anak usia dini merupakan dasar penting sejak dilahirkan sampai memasuki jenjang pendidikan dasar, maka pendidikan anak usia dini dapat diselenggarakan melalui jalur pendidikan formal, nonformal, dan/atau informal yang bukan merupakan prasyarat untuk jenjang pendidikan dasar. ${ }^{10}$ Pendidikan Anak Usia Dini adalah suatu upaya pembinaan yang ditujukan kepada anak sejak lahir sampai dengan usia enam tahun yang dilakukan melalui pemberian rangsangan pendidikan untuk membantu pertumbuhan dan perkembangan jasmani dan rohani agar anak memiliki kesiapan dalam memasuki pendidikan lebih lanjut. Karena menurut Nurani pendidikan Anak Usia Dini, lebih menekankan pada arah pertumbuhan dan perkembangan psikomotorik, motorik halus dan kasar, kognitif (daya pikir, daya cipta, kecerdasan emosi, kecerdasan spiritual), afektif (sikap dan perilaku serta beragama), bahasa dan komunikasi, sesuai dengan keunikan dan tahap-tahap perkembangan yang dilalui oleh anak usia dini. ${ }^{11}$ Hal-hal seperti ini yang harus diperhatikan oleh orang tua, tetapi orang tua tidak semua memiliki pengetahuan dalam memahami mendampingi anak, sebagaimana yang disampaikan oleh Nurani di atas sehingga banyak orang tua saat ini mengharapkan sekolah segera dibuka atau tatap muka, karena orang tua

${ }^{6}$ Meike Elsa Toisuta Jane Gresia Akollo, "Keterlibatan Orang Tua Dalam Pembelajaran Anak Usia Dini Selama Belajar Dari Rumah Di Masa Pandemi Covid-19," INSTITUTIO: Jurnal Pendidikan Agama Kristen 6, no. 2 (2020): 70.

${ }^{7}$ Hairuddin, "Pendidikan Itu Berawal Dari Rumah,” Jurnal Irfani 10, no. 1 (2014): 75.

${ }^{8}$ Eva Mufaziah and Pujiyanti Fauziah, "Kendala Orang Tua Dalam Mendidik Anak Usia Dini Pada Saat Pandemi Covid 19," Jurnal Obsesi : Jurnal Pendidikan Anak Usia Dini 5, no. 2 (2020): 1045.

${ }^{9}$ Anita Wardani and Yulia Ayriza, "Analisis Kendala Orang Tua Dalam Mendampingi Anak Belajar Di Rumah Pada Masa Pandemi Covid-19,” Jurnal Obsesi : Jurnal Pendidikan Anak Usia Dini 5, no. 1 (2020): 782.

${ }^{10}$ Undang-Undang Republik Indonesia Nomor 20 Tahun 2003 Sistem Pendidikan Nasional, 2003. Pasal 28.

${ }^{11}$ Nurani, 264

206 | Copyright $\odot$ 2021, CARAKA, ISSN 2722-1407 (Cetak), 2722-1393 (Online) 
menagalami kesulitan yang cukup membembani sebagaimana yang telah di jelaskan oleh Wardani dan Ayriza; Rismag dan Tafonao di atas. Berdasarkan latar belakang tersebut maka yang menjadi rumusan masalah ialah bagaimana upaya orang tua dalam mendidik anak-anak (usia dini) selama masa pandemi? Berdasarkan rumusan masalah tersebut maka tujuan penulisan karya ilmiah ini adalah untuk membangun sikap optisme orang tua dalam mendidik anak selama pandemi.

Banyak penelitian yang membahas mengenai pendidikan usia dini di rumah. Salah satunya adalah Prinsip-Prinsip Mendidik Anak Usia 0-12 Tahun Berdasarkan U1. 6:1-9 yang dilakukan oleh Dowansiba (2018). Penelitian ini menjelaskan bahwa, tumbuh kembang seorang anak ditentukan oleh cara oang tua dan guru dalam mendidik. ${ }^{12}$ Ada juga penelitian yang berjudul Pendidikan Itu Berawal Dari Rumah yang dilakukan oleh Hairuddin. ${ }^{13}$ Dimana penelitian ini berkesimpulan bahwa, Orangtua bertanggung jawab terhadap tumbuh kembang anak, terutama dalam pemberian nutrisi fisik dan nutrisi rohani. Kedua penelitian tersebut di atas sama-sama menjelaskan pentingnya pendidikan anak di dalam rumah. Namun belum menjelaskan bagaimana rumah menjadi tempat belajar yang tidak kalah penting dengan keadaan seperti di sekolah serta menyiapkan kebutuhan belajar anak baik secara psikologi maupun kebutuhan lain yang mendukung aktifitas anak sepanjang di rumah khususnya di masa pandemi. Oleh karena itu artikel ini penting dikaji untuk memahami tanggung jawab orang tua dalam mendidik anak selama pandemi.

\section{METODE PENELITIAN}

Metode yang digunakan dalam penelitian ini adalah penelitian kualitatif deskriptif. ${ }^{14}$ Dalam penelitian deskriptif ini, penulis akan menggali berbagai literatur yang berkaitan dengan Mengembalikan Pendidikan Anak Usia Dini di Rumah Sebagai Bentuk Tanggung Jawab Orang Tua Selama Pandemi. Selain itu penulis juga menggunakan teks-teks paralel Alkitab yang mendukung tanggung jawab orang tua dalam mendidik anak selama pandemi, karena hal itu akan mendapatkan makna dan prinsip pendidikan sesungguhnya dalam keluarga. Setelah melakukan hal itu maka penulis menggunakan berbagai sumber-sumber literatur-literatur baik jurnal, buku dan bahan referensi lainnya yang terpercaya untuk mendukung analisis penulis.

\footnotetext{
12 Agustina Dowansiba, "Prinsip-Prinsip Mendidik Anak Usia 0-12 Tahun Berdasarkan Ulangan 6:1-9," Logon Zoes: Jurnal Teologi, Sosial dan Budaya 1, no. 2 (2018): 100.

${ }^{13}$ Hairuddin, "Pendidikan Itu Berawal Dari Rumah."

${ }^{14}$ Nursapiah, Penelitian Kualitatif (Medan: Wal Ashri Publising, 2020): 196.
} 


\section{HASIL DAN PEMBAHASAN}

\section{Hakikat pendidikan anak usia dini}

Pendidikan Anak usia Dini merupakan sesuatu yang sangat penting untuk diajarkan nilai-nilai Alkitabiah. Pendidikan harus berpusat dari rumah karena banyak hal yang akan dihadapi anak-anak sejak usia dini di luar pengawasan keluarga. ${ }^{15}$ Pengalaman penulis di Eropa, pendidikan untuk anak usia dini sangatlah memprihatinkan saat ini dimana pendidikan di sekolah tidak mengutamakan menanamkan nilai-nilai kekristenan kepada anak usia dini, sehingga banyak anak-anak yang tumbuh dalam masalah-masalah kenakalan yang membuat kerugian bagi anak. Bagaiamana pun hal ini terjadi, orang tua harus bertanggung jawab dalam mendidik anak karena itu adalah perintah Tuhan. Dengan demikian dalam menghadapi situasi pandemi sekarang banyak anak-anak yang mengalami stres, karena anak-anak merindukan suasana belajar bersama dengan teman-temannya di sekolah. Suasana belajar di sekolah (onsite) karena sangat berbeda dengan suasana belajar di rumah sehingga banyak anak-anak yang tidak betah untuk belajar di rumah. Selain itu, orang tua juga bekerja dari rumah dan ini sangat menjadi masalah besar apabila orang tua tidak memperhatikan anak-anak saat belajar secara online. Dan apabila anak kurang disiplin akan menimbulkan masalah besar bagi anakanak, seperti membantah setiap perintah orang tua. Bila diperhatikan dengan seksama, bahwa hal ini tidak sepenuhnya anak-anak di salahkan karena hal ini sebabkan kurangnya pendampingan orang tua disaat anak-anak di rumah. Pendidikan pertama kali diterima dan dilakukan di dalam keluarga. Menurut Marisi, keluarga Kristen adalah tempat pendidikan yang pertama mengajarkan dan menjalankan misi Allah kepada anak-anak. ${ }^{16}$ Pendidikan Anak Usia Dini menitikberatkan pada peletakkan dasar ke arah pertumbuhan dan perkembangan psikomotorik, afektif, kognitif, sosial, spiritual, bahasa dan komunikasi sesuai dengan keunikan dan tahap-tahap perkembangan yang dilalui oleh anak usia dini. ${ }^{17}$ Dengan demikian penulis berpendapat bahwa orang tua harus mempersiapkan diri untuk menjadi ayah atau ibu dan sekaligus menjadi guru bagi anak-anak dalam keluarga dimasa pandemi ini, karena pendidikan sudah dimulai bahkan sejak anak-anak masih dalam kandungan.

\section{Pentingnya Pendidikan Anak Usia Dini}

Pendidikan usia dini merupakan sesuatu hal yang sangat penting untuk mendapatkan perhatian dari semua pihak yang bertanggung jawab, sejak anak dilahirkan sampai masuk

${ }^{15}$ Desy Harefa, "Kontribusi Pendidikan Kristen Bagi Pembentukan Rohani Dan Perilaku Anak Usia Dini," Real Didache: Jurnal Teologi Dan Pendidikan Agama Kristen 4, no. 2 (2019):120.

${ }^{16}$ Candra Gunawan Marisi, Didimus Sutanto, and Ardianto Lahagu, "Keluarga Sebagai Pusat Misi Masa Kini," in Konfrensi Keluarga Kristen - The Great Commission, vol. 1 (Batam: Stt Real Batam, 2020), 91.

${ }^{17}$ Nurani, Perspektif Baru Konsep Dasar Pendidikan Anak Usia Dini. 
pendidikan formal, pendampingan orang tua dan orang dewasa lainnya sangat potensial untuk membentuk karakter anak. Pembalajaran pada anak usia dini sangat potensial dilakukan di rumah oleh orang tua, karena pada masa ini terdapat masa peka atau masa sensitif dimana anak mudah menerima beragam rangsangan dan pengaruh dari luar diri yang diterimanya melalui panca inderanya. Selain itu kemampuan kognitif, bahasa, fisik motorik dan emosional, anak juga mengalami kematangan dan perubahan yang cepat seiring dengan pengaruh dari lingkungannya. Penulis setuju dengan pendapat Wijoyo bahwa, pendidikan anak usia dini adalah pendidikan untuk membantu pertumbuhan dan perkembangan jasmani dan rohani. ${ }^{18}$

Tujuan utama dari pembelajaran pada anak usia dini, yang dicirikan dengan prinsip bermain sambil belajar melalui pengalaman nyata yang bermanfaat dalam kehidupan seharihari untuk membantu seoptimal mungkin menumbuh kembangkan semua potensi yang dibawa anak sejak lahir dan untuk membangun pondasi yang kuat terhadap pengenalan akan iman dan takut akan Tuhan.

Proses pembelajaran pada anak usia dini seharusnya memiliki kebermaknaan melalui pengalaman nyata yang bermanfaat dalam kehidupan sehari-hari, dengan demikian orang tua menjadi guru dan teladan bagi anak. Pendidikan Anak Usia Dini juga harus disesuaikan dengan nilai-nilai yang ada disekitarnya yang meliputi faktor budaya, keindahan, kesenian dan kebiasaan-kebiasaan sosial yang dapat dipertanggungjawabkan. Masa pendidikan anak usia dini merupakan peletakan dasar atau pondasi awal bagi pertumbuhan dan perkembangan selanjutnya. Dengan demikian perlu membuat situasi dan kondisi yang kondusif pada saat memberikan stimulasi dan upaya-upaya pendidikan yang sesuai dengan kebutuhan anak yang berbeda satu dengan yang lainnya (individual differences). Secara ontologis, anak sebagai makhluk individu yang mempunyai aspek biologis (adanya perkembangan fisik yang berubah dari waktu ke waktu yang membutuhkan makanan, gizi, dan lain-lain), psikologis (adanya perasaan-perasaan tertentu yang terbentuk karena situasi, seperti: senang, sedih, marah, kecewa, dihargai, dan sebagainya), sosiologis (anak membutuhkan teman untuk bermain), antropologis (anak hidup dalam suatu budaya dari mana dia berasal). Secara epistomologis, pembelajaran pada anak usia dini haruslah menggunakan konsep belajar sambil bermain (learning by playing), belajar sambil berbuat (learning by doing), dan belajar melalui stimulasi (learning by stimulating). Secara aksiologis, isi kurikulum haruslah benar dan dapat dipertanggungjawabkan dalam rangka optimalisasi seluruh potensi anak (etis) dan berhubungan dengan nilai seni, keindahan dan keselarasan yang mengarah pada kebahagiaan

${ }^{18}$ Irjus Indrawan and Hadion Wijoyo, Pendidikan Anak Pra Sekolah, ed. Abdul Rahmat, vol. 1 (Jawa Tengah: CV. Pena Persada, 2020): 105.

209 | Copyright@ 2021, CARAKA, ISSN 2722-1407 (Cetak), 2722-1393 (Online) 
dalam kehidupan anak sesuai dengan akar budaya di mana mereka hidup (estetika) serta nilainilai agama yang dianutnya. ${ }^{19}$

\section{Kondisi Psikologi Anak Usia Dini Dimasa Pandemi}

Sistem Pendidikan di dalam rumah anak usia dini selama masa pandemi merupakan situasi realitas baru yang juga dialami dunia pendidikan, yang sebelumnya belum pernah terjadi. Pembelajaran dan pengajaran pada anak usia dini dalam kondisi seperti ini sangat berdampak terhadap psikologi anak seperti stres yang akan mempengaruhi perilaku mental, dan perkembangan sosial emosional. Perlu diketahui bahwa aspek perkembangan sosial dan aspek perkembangan emosional merupakan aspek yang saling berhubungan, karena perkembangan sosial berkaitan dengan kemampuan anak berinteraksi dengan orang lain, sedangkan perkembangan emosional terkait dengan kemampuan anak mengelola emosi secara efektif ketika berinteraksi. ${ }^{20}$ Penurunan pencapaian perkembangan pro-sosial ini kemungkinan terjadi karena selama pembelajaran di rumah anak-anak tidak dapat melakukan interaksi sosial dengan orang lain khususnya guru dan teman-temannya, padahal pencapaian perkembangan prososial melibatkan interaksi yang responsif secara positif terhadap kebutuhan dan kesejahteraan orang lain. ${ }^{21}$

Berdasarkan kondisi yang disampaikan di atas, penulis berpendapat bahwa kondisi pandemi berpengaruh negatif terhadap psikologi anak, mulai dari perkembangan sosial emosianal yang tidak bisa bermain dengan teman sebaya di sekolah, kurangnya waktu orang tua dalam menemani anak di rumah, anak usia dini merupakan masa anak-anak banyak waktu bermain dan waktu bersosialisasi tetapi sebagian orang tua kurang menyadari hal tersebut, karena sebagian orang tua banyak berfokus kepada kegiatan-kegiatan belajar demi mengejar prestasi akademik di sekolah. Hal tersebut memang tidak salah, namun kebutuhan anak untuk bermain hendaknya jangan diabaikan karena bermain adalah hal penting bagi perkembangan fisik dan mental anak. Orang tua harus mengenali metode yang baik untuk mengenal dan menguasai psikologi anak terlebih dimasa pandemi ini, orang tua dapat mengamati psikologi anak dari gerak-gerik anak, respon anak terhadap sesuatu kejadian dan bagaimana anak mengenali dirinya sendiri. Lingkungan yang tepat sangat berpengaruh untuk perkembangan psikologi anak. $^{22}$

${ }^{19}$ Nurani, 264.

${ }^{20}$ Santrock J. W, “Child Development,” New York: McGraw Hill Education (2014): 38.

${ }^{21}$ Toseeb U et al., "Prosociality from Early Adolescence to Young Adulthood: A Longitudinal Study Ofindividuals with a History of Language Impairment. Research in Developmental Disabilities" 62 (2017): 150.

22 Darianti and Talizaro Tafonao, "Problem Pembelajaran Pendidikan Agama Kristen Dimasa Pandemi Terhadap Psikologi Anak,” Sanctum Domine: Jurnal Teologi 10, no. 2 (2021): 56. 


\section{Konsep Pendidikan di dalam Rumah Berdasarkan Ulangan 6:6-7}

Pendidikan iman dalam konteks Israel dapat berdimensi ganda, yakni pendidikan tidak hanya menyangkut dimensi etis, tetapi juga dimensi historis, ${ }^{23}$ Orang israel sejak usia dini, mereka sudah diajarkan tentang karya penyelamatan Allah dalam sejarah nenek moyang mereka (dimensi historis) sekaligus mereka diajak untuk belajar cara hidup dan berkelakuan sopan dan pantas (dimensi etis) sebagai konsekuensi logis dari pengalaman Allah yang menyelamatkan. Hal ini dimaksudkan supaya konteks penceritaan kembali kisah-kisah penting dalam sejarah Israel tidak hanya sekedar untuk pengetahuan belaka, tetapi berusaha membawa anak-anak untuk masuk kedalam pengalaman nenek moyang mereka melalui peran orang tua.

Orang Israel sadar akan pemahaman bahwa anak-anak merupakan harapan masa depan. Kebaikan dan perilaku seluruh umat atau bangsa ditentukan bagaimana orang tua memperlakukan dan bagaiamana cara mendidik anak-anak. Penulis mengutip sebuah cerita didalam Talmud tentang seorang laki-laki menanam pohon yang akan berbuah tujuh puluh tahun lagi. Ketika ditanya apakah ia nanti masih hidup ketika pohon itu berbuah, ia menjawab, "Saya melakukan hal yang sama dengan yang dilakukan para nenenk moyang saya. Sebagaimana mereka menanam pohon agar anak-anak mereka dapat memakan buahnya, demikianlah saya menanam pohon ini agar anak-anak saya dapat memakan buahnya." ${ }^{24}$

Berdasarkan cerita itu bahwa masa anak usia dini adalah masa yang penuh kesucian, kegembiraan, dan keindahan yang patut kita hargai dan hormati. Masa anak usia dini diumpamakan sebagai karangan bunga mawar dan nafas anak-anak bebas dari dosa. Oleh karena itu jangan heran jika anak-anak dianggap belum memiliki kemampuan kognitif sepenuhnya untuk membedakan kebaikan dan kejahatan. Sebagai orang tua dalam hal ini mempunyai tanggung jawab utama membimbing anak sesuai dengan kehendak Tuhan. Sebagai orang tua dan orang dewasa disekitar anak usia dini memiliki tanggung jawab yang sangat besar karena pendidikan dalam konteks sekarang ini memiliki tempat istimewa sebab membekali anak-anak dengan nilai-nilai yang harus dipelajari untuk hidup kudus, moral,dan spiritual sehingga anak-anak in menjadi generasi mendatang.

Allah menghendaki setiap orang tua menceritakan kembali karya Allah dimasa sejarah Israel sebagai pengingat sebagaimana yang dilakukan oleh bangsa Israel. Dengan kata lain Allah menghendaki setiap orang tua mendidik anak-anaknya dalam iman kepada Allah yang telah mengasihi manusia. Tugas dan tanggung jawab orang tua sangat besar, dimana pandemi

${ }^{23}$ V. Indra Sanjaya, "Pendidikan Iman: Belajar Dari Tradisi Kuno,” Wacana Biblika 9, no. 1 (2009): 8.

${ }^{24}$ Y. M. Seto Marsunu, "Pendidikan Iman Anak Dalam Perjanjian Lama Dan Tradisi Yahudi,"," Wacana Biblika 13, no. 4 (2013): 149. 
sekarang ini anak-anak belajar dari rumah dan ini juga merupakan suatu kesempatan besar sebagai orang tua untuk melakukan kehendak Allah, yakni mendidik anak-anak dalam iman sebagaimana yang diperintah oleh Allah dalam Alkitab, Jadi penulis menegaskan tugas sebagai orang tua ini memiliki nilai amat tinggi karena Allah sendiri yang menghendakinya. Kita sebagai orang tua patutlah merasa bangga karena Allah sendiri yang menyerahkan tanggung jawab kepada kita untuk mendidik anak-anak yang lahir dalam keluarga.

Rumah dan keluarga adalah tempat dalam membentuk karakter anak usia dini sebagai generasi masa depan keluarga dan bangsa. Dalam masyarakat kuno, keluarga tidak hanya mencakup keluarga inti (ayah, ibu dan anak) tetapi mencakup keluarga besar yang disebut bet $a b$ (rumah bapak), Menurut beberapa ahli, sebuah bet ' $a b$ terdiri atas tiga atau lima generasi yang hidup bersama dibawah pimpinan satu kepala keluarga tunggal (singel patriarch). ${ }^{25}$ Dengan melihat konteks ini, sebagai orang tua memiliki peran yang sangat besar karena orang tua sebagai perpanjangan tangan Allah untuk mendidik anak-anak yang dipercayakan kepada mereka. Sebagai wakil Allah terkait peran orang tua dalam melakukan reinterpretasi terhadap teks yang dikenal sebagai hukum kelima dari dasar titah yaitu menghormati orang tua (Kel. 20:12). Menurut Sanjaya, kata hormat dalam teks tersebut berasal dari bahasa Yunani kabed yang memiliki arti yang lebih luas dari sekedar menghormati. Kata tersebut mengandung arti memelihara termasuk memperhatikan kebutuhan fisik orang tua. ${ }^{26}$ Akan tetapi, perintah tersebut tetaplah perintah menghormati orang tua secara de facto juga terdapat dalam tradisitradisi lain didunia lain. ${ }^{27}$

Hal yang diceritakan dalam Ul. 6:6-7, adalah perintah Tuhan yang diberikan melalui Musa. Kisah ini secara besar menceritakan tentang bagaiamana manusia mendidik anaknya supaya mengenal dan mengetahui apa yang sudah dilakaukan Tuhan terhadap bangsa Israel, yaitu membawa mereka keluar dari tanah perbudakan ke tanah Perjanjian. Musa menyampaikan perintah Tuhan dari atas gunung, Ia menyampaikan perintah Tuhan yang paling utama yaitu manusia harus mengasihi Tuhan yang sudah menuntun mereka keluar dari Mesir dan kemudian mereka juga harus memperkenalkan Tuhan kepada keturunannya dengan terus menerus bahwasannya Tuhan sudah sangat berjasa untuk bangsa ini.

Perintah yang diturunkan Allah melalui Musa (Ay. 6). Kata "haruslah kau mengajarkannya berulang-ulang kepada anak-anakmu" kalimat ini menggunakan kata kerja

${ }^{25}$ Rainer Albertz and Rudiger Schmitt, Family and Household Religion in Ancient Israel and the Levant (Winona Lake: Eisenbrauns, 2012): 25.

${ }^{26}$ V. Indra Sanjaya, "Hormatilah Ayahmu Dan Ibumu: Penghormatan Terhadap Orangtua Dalam Perspektif 'Perintah Utama,” Wacana Biblika 13, no. 2 (2013): 54.

27 Ibid. 
piel yang artinya mempertajam dan dalam istilah ugrnit adalah mengulang. Kata kerja ini adalah pokok dari ayat ini. Pendidikan agama Yahudi adalah sebuah poros dalam kehidupan sehari-hari sehingga para orang tua juga dituntut agar wajib menjadi pelajar selama hidup mereka. Menurut Boehlke tujuan dari pendidikan ini adalah melibatkan angkatan muda dan dewasa dalam sejumlah pengalaman belajar yang menolong mereka mengingat perbuatanperbuatan ajaib yang dilakukan Allah pada masa lampau, serta membimbing mereka mengharapkan terjadinya perbuatan sama dengan pertanyaan ditengah-tengah kehidupan mereka guna memenuhi syarat-syarat perjanjian-perjanjian, hal yang berkaitan dengan kebaktian keluarga dan seluruh persekutuan maupun yang mencakup perilaku yang sesuai dengan kehendak Tuhan, sebagaiamana ia diperintahkan dalam urusan sosial dan pemiliharaan ciptaan yang dinamakan baik oleh Tuhan. ${ }^{28}$ Sebagai orang tua harus membicarakan kehendak Allah setiap hari karena pada zaman sekarang ini sekolah dan gereja tidak bisa mengambil peran orang tua untuk anak. Orang tualah yang bertugas meneruskan gaya hidup iman kepada anak-anak (Ul. 6:20-25,4:9). Dalam teks Ul. 6:7 tertulis jelas perintah Tuhan agar mengajarkan perintah Tuhan ke pada anak-anak secara berulang-ulang. Dalam bahasa ibrani shanan yang berarti mengajarkan secara rajin. Menurut Calvin kata shanan yang digunakan oleh Musa dalam ayat tersebut berarti "untuk mengasah." Mengajarkan secara terus menerus, artinya proses pembelajaran dilakukan setiap waktu saat orang tua bersama-sama anakanaknya, sehingga orang tua dapat terus mengasah ingatan anak-anak tentang pokok-pokok iman di dalam Alkitab. Proses pembelajaran yang menekankan pada ingatan tersebut dengan memanfaatkan berbagai media seperti mengikatkan tanda pada tangan dan membuat lambang di dahi kemudian menuliskan pada tiang pintu rumah serta pada pintu gerbang tindakan tersebut dilakukan dengan penuh hormat dan kesungguhan agar bangsa Israel menanamkan perintah Tuhan di dalam hati mereka dengan maksud anak-anak dapat tumbuh dengan baik. Teks Ul. 6:6-7 tentunya akan mendorong orang tua Kristen memiliki lebih banyak waktu untuk belajar dan berbicara tentang Firman Tuhan, baik saat duduk maupun berjalan.

Dengan proses pengulangan sesuai teks Ul. 6:6-7 tersebut menghasilkan informasi yang direkam dan disimpan. Artinya bahwa semakin banyak informasi yang disampaikan oleh orang tua kepada anak-anak secara terus menerus dalam berbagai situasi, maka anak-anak dapat lebih mudah mengingat informasi tersebut dan memahaminya dengan baik. Pembelajaran memorisasi dilaksanakan dengan menggunakan komunikasi verbal selain non verbal menggunakan simbol, gambar dan tulisan, ini semua dapat menolong anak-anak mudah

${ }^{28}$ R. Boehlke Robert, Sejarah Perkembangan Pikiran Dan Praktek Pendidikan Agama Kristen (Jakarta: BPK Gunung Mulia, 2009): 23.

213 | Copyright@ 2021, CARAKA, ISSN 2722-1407 (Cetak), 2722-1393 (Online) 
memahami informasi lebih konkrit jika membicarakannya secara terus menerus. Maksud kata berulang-ulang dalam teks Ulangan merupakan suatu metode dalam mengajarkan anak-anak. ${ }^{29}$

Sedangakan menurut penjelasan Lasor bahwa kalimat "haruslah engkau mengajarkannya berulang-ulang kepada anak-anakmu" Ul. 6:7 lebih dimaknai dengan ketekunan sebagai bagian ibadah bangsa Israel dalam kehidupan sehari-hari. ${ }^{30}$

\section{Implikasi Pendidikan Anak Usia Dini di Dalam Rumah Berdasarkan Ulangan 6:6-7}

Pada masa sekarang pendidikan bagi anak usia dini dengan situasi yang dialami hampir seluruh manusia di bumi, tentunya hal ini bukan suatu penghalang bagi orang tua dan orang dewasa yang ada disekitar mereka untuk memberikan pengajaran bagi anak usia dini justru ini dijadikan kesempatan untuk berperan penting penuh untuk memberikan pembelajaran kepada anak usia dini hal-hal yang mudah untuk mereka belajar mengenal apa yang ada disekitar mereka. Oleh karena itu, pendidikan Agama seharusnya mendapat tempat selayaknya dalam keluarga untuk diajarkan kepada anak-anak. Tugas ini dipercayakan kepada keluarga sebagai Pendidikan pertama dalam keluarga. Didalam Kitab Ulangan telah mengingatkan setiap orang tua bahwa "Apa yang diperintahkan kepadamu hari ini haruslah engkau perhatikan, haruslah engkau mengajarkannya berulang-ulang kepada anak-anakmu dan membicarakannya apabila engkau duduk dirumahmu, apabila engkau sedang dalam perjalanan, apabila engkau berbaring, dan apabila engkau bangun. Haruslah juga engkau mengikatnya sebagai tanda pada tanganmu dan haruslah itu menjdai lambang di dahimu, dan haruslah engkau menuliskannya pada tiang pintu rumahmu, dan pada gerbangmu" (Ul. 6: 6-7). Dalam ayat 7 dicatat istilah "mengajarkan”! Mengapa bukan istilah mendidik? Mendidik pada hakekatnya adalah relasi. Jadi harus ada relasi antara pendidik dan yang dididik. Ini berbicara juga masalah keteladanan yang dapat diberikan oleh pendidik kepada yang dididik. ${ }^{31}$

Setiap keluarga Kristen harus memiliki komitmen dan tanggung jawab untuk membina kerohanian anak sejak usia dini. Keluarga yang luar biasa adalah keluarga yang senantiasa mengajarkan dan menghidupi Firman Allah, baik waktu sedang duduk-duduk di rumah, sedang dalam perjalanan, sedang berbaring, ataupun sedang bangun. Biarlah Firman Tuhan itu sungguh-sungguh menjadi suatu pelita dan terang didalam keluarga.

${ }^{29}$ Manurung and Tafonao, "Problem Pembelajaran Online Di Masa Pandemi Terhadap Psikologi Anak Usia 10-12 Tahun.”

${ }^{30}$ WS. Lasor, Pengantar Perjanjian Lama (Jakarta: BPK Penabur, 1985): 253.

${ }^{31}$ Talizaro Tafonao, "Peran Pendidikan Agama Kristen Dalam Keluarga Terhadap Perilaku Anak," Edudikara: Jurnal Pendidikan dan Pembelajaran, Vol 3 (2), 2018 ISSN 2541-0261 3, no. 2 (2018): 130. 


\section{Orang tua sebagai pengajar utama}

James Kenny dan Kenny menerangkan bahwa perkembangan diri adalah tujuan pertama diantara kedua tujuan pendidikan anak yang baik. Anak harus dididik oleh orang tuanya di sepanjang jalan menuju ke penghargaan diri yang paling penuh. Tujuan dasar kedua bagi para orang tua, yaitu membantu anak mengembangkan kemampuan untuk mencintai orang lain. ${ }^{32}$ Jadi penulis menyimpulkan bahwa orang tua adalah pendidik yang berpengaruh bagi anakanaknya, dengan selalu memberikan contoh hal-hal yang baik dalam kehidupan sehari-hari, bertutur kata dengan baik yang bisa membuat anak-anak mendengarkan dengan baik dan anakanak bisa secara langsung mempraktekannya dalam kesehariannya, karena anak-anak dimasa sekarang akan banyak melihat apa yang ada disekitar mereka jadi sebagai orang tua perlu sadar dengan benar bahwa selain menjadi orang tua, orang tua juga menjadi pengajar utama bagi anak-anak di rumah dengan kata lain orang tua sebagai contoh paling dekat dengan anakanak.

\section{Orang tua mengajar dan mendidik anak berdasarkan konsep Alkitab}

Ul. 6:4-9 ini sering disebut sebagai Shema yang artinya mendengar. Bagian ini sangat dikenal oleh orang Yahudi yang saleh dan secara tetap dalam kebaktian-kebaktian. Shema ini merupakan pernyataan yang terbaik tentang kodrat monoteisme Allah. Melalui pernyataan tersebut, disampaikanlah perintah bagi bangsa Israel yaitu U1. 6:5-6, diperintahkan untuk mengasihi Tuhan Allah dengan segenap hati, jiwa, dan kekuatan dan Ul. 6:7-9, untuk senantiasa mengajarkan iman mereka dengan tekun kepada anak-anak mereka. ${ }^{33}$ Maka menjadi orang tua mempunyai tanggung jawab terus mendidik anak-anak dalam Tuhan, melalui cara hidup yang mengasihi Allah, ketaatan dan keteladanan dalam melakukan perintah Tuhan serta terus mengajarkan Firman Tuhan secara berulang-ulang kepada anak-anak. Orang Tua harus memberi teladan hidup bagi anak-anaknya, ketika anak-anak melihat bahwa orang tua mereka tekun dalam persekutuan pribadi dengan Tuhan dalam doa dan membaca Firman setiap hari serta hidup penuh kasih terhadap orang-orang yang ada disekitar mereka, itu bisa menjadi motivasi untuk anak-anak melakukannya sama seperti apa yang dilakukan oleh orang tua mereka. Orang tua menjadi role model kehidupan bagi anak-anak.

Orang tua berfungsi sebagai motivator bagi anak, dengan motivasi melalui pendampingan dan kata-kata meneguhkan, anak-anak akan merasa berani untuk mencoba. Karena dengan kata-kata yang sederhana sejak dini dan masuk kedunia mereka sebagai teman

32 James Kenny and Mary Kenny, Dari Bayi Sampai Dewasa (Jakarta: BPK Gunung Mulia, 1988): 67.

${ }^{33}$ Reni Sandy Donnalo, "Implementasi Pendidikan Dalam Ulangan 6:1-9 Kepada Anak Sekolah Minggu Kelas Besar Dengan Menggunakan Metode Role Play,” IAKN Toraja 2, no. 1 (2020): 5. 
bermain, mereka akan lebih cepat paham dengan apa yang kita sampaikan atau contohkan kepada mereka. Sejak anak-anak sudah mengerti tentang sesuatu orang tua harus mendorong anak untuk berani melakukan sesuatu hal, contohnya berdoa, berenang, memilih pakaian yang akan dia pakai kesekolah, dan hal-hal baru lain baginya. Saat anak-anak sudah mengerti orang tua harus membiasakan diri untuk berdiskusi dengan anak-anak menyangkut keperluan mereka dan apa yang mereka akan lakukan. Saat ini sangat lah penting peran orang tua dimana keadaan pendidikan berpusat dari rumah, orang tua bisa membiasakan hal-hal yang bisa anakanak lakukan dengan melihat contoh dari orang tua seperti membiasakan berdiskusi tentang Firman Tuhan disaat duduk bersama keluarga dan membacakan cerita-cerita alkitab kepada anak-anak dengan kata-kata yang membuat mereka mudah pahami sehingga dengan mendengarkan dan melihat kebiasaan orang tua dirumah, mereka termotivasi juga untuk melakukan seperti apa yang dilakukan oleh orang tua. Wyclife mengatakan, "unsur kekeluargaan dari administrasi perjanjian mengharuskan bahwa anak-anak juga dituntun kepada ketaatan pada peraturan-peraturan yang ada. Orang saleh harus merenungkan hukum Allah tersebut siang dan malam. Wiclife ingin menjelaskan bahwa dengan merenungkan siang dan malam maka pemikiran dan pengetahuan tentang Allah itu akan semakin mendalam sehingga untuk memperkatakan kepada anak akan semakin baik. ${ }^{34}$

\section{Orang tua menjadi teladan bagi anak dalam segala aspek}

Secara moral dan rohani, orang tua mendidik anak-anak tentang nilai-nilai kualitas hidup seperti kejujuran, hormat, tanggung jawab, belas kasihan, kesabaran, pengampunan, murah hati dan lain-lain. ${ }^{35}$ Tapi tidak kalah pentingnya orang tua harus mendidik anak menjadi teladan dengan melihat orang tua teladan akan ajaran Firman Tuhan dan melakukannya setiap hari dan teladan sebagai pengikut Kristus yang setia. Dengan adanya keteladanan dari orang tua, maka anak-anak bisa belajar menjadi pengikut Kristus yang setia sehingga anak-anak membawa dampak besar terhadap lingkungannya dengan melihat teladan dari orang tua yang setia membaca Firman Tuhan, setia berdoa, mengasihi orang lain, ini merupakan kunci utama dalam mendidik anak sejak dini. Konsep keteladanan menurut Tafonao suatu tindakan yang benar yang berdampak positif bagi orang lain (anak-anak). ${ }^{36}$ Dengan melihat keteladanan tersebut maka anak-anak juga bisa menjadi teladan kepada anak-anak lain, seperti di sekolah, gereja dan masyarakat. Dan ini yang diajarkan oleh Yesus kepada murid-murid-Nya "sebab

${ }^{34}$ Wyclife, Tafsiran Alkitab (Malang: Gandum Mas, 2014): 105.

${ }^{35}$ Adewumi Moradeke Grace, Olojo Oludare Jetro, and Falemu Funke Aine, "Roles of Parent On The Academic Performance Of Pupils IIn Elementary Schools," international journal pf academic Research in business and Social Sciences 2, no. 1 (2021): 184.

36 Talizaro Tafonao, "Peran Guru Agama Kristen Dalam Membangun Karakter Siswa Di Era Digital," Journal BIJAK Basileia Indonesian Journal of Kadesi 2, no. 1 (2018): 29. 
Aku telah memberikan suatu teladan kepada kamu, supaya kamu juga berbuat sama seperti yang telah Kuperbuat kepadamu (Yoh. 13:15). Pesan Yesus dalam ayat ini bahwa tidak hanya sekedar mengajar dan mendidik murid-murid-Nya tetapi pengajaran-Nya dapat diperlihatkan melalui tindakan yang nyata bagi semua orang sebagaimana yang uangkapkan dalam Injil Matius 5:13. Hendaknya hal ini dapat dilihat oleh anak-anak dalam keluarga bersama dengan orang tua selama pandemi.

\section{Orang tua menyediakan waktu dalam pendampingan anak}

Dimasa pandemi sekarang ini, orang tua dituntut untuk bekerja keras dalam mendampingi anak-anak pada saat belajar secara online, tetapi disisi lain sering kali orang tua menghadapi berbagai tantangan. Salah satu tantangan yang dihadapi oleh orang tua dalam mendampingi anak belajar di masa pandemi adalah tingkah laku anak yang tidak mudah diatur oleh orang tua dalam belajar online. Dalam penelitian yang dilakukan oleh Astuti dan Harun menyarankan bahwa salah satu cara menghadapi anak-anak belajar di masa pandemi adalah orang tua memahami mood anak dalam belajar. ${ }^{37}$ Jadi penulis menyimpulkan bahwa, Perhatian, kasih sayang serta memperlihatkan sikap positif adalah salah satu pola pendidikan yang harus diterapkan dalam keluarga yang dapat memotivasi anak bersikap baik, sehingga perintah Tuhan dalam Kitab Ul. 6:6-7 dapat terealisasikan dengan baik. Kasih sayang orang tua yang lebih penting dari seribu kata atau barang-barang berharga, karena kasih sayang orang tua menjadi satu filter bagi anak dalam menghadapi berbagai persoalan yang ada.memiliki hati mengasihi ssebagai orang tua berarti mencintai dan menyayangi. Dengan rangkaian kata asah-asih-asuh, maka penngasuhan anak bertujuan utnuk meningkatkan atau mengembangkan kemampuan anak dan dilakukan dengan dilandasi rasa kasih sayang tanpa pamrih. ${ }^{38}$ Oleh karena itu, menurut hemat Manurung dan Tafonao bahwa orang tua harus berupaya menjalankan tanggung jawabnya sebagai guru dan orang tua dalam mendampingi anak belajar daring. ${ }^{39}$

\section{Orang tua sumber pembelajaran bagi anak}

Hal lain yang bisa dilakukan orang tua dirumah selama pendidikan berpusat dalam rumah adalah menyiapkan bahan-bahan ajar yang bisa digunakan sebagai bahan untuk

${ }^{37}$ Isti Yuli Astuti and Harun Harun, "Tantangan Guru Dan Orang Tua Dalam Kegiatan Belajar Dari Rumah Anak Usia Dini Pada Masa Pandemi Covid-19," Jurnal Obsesi : Jurnal Pendidikan Anak Usia Dini 5, no. 2 (2020): 1463.

${ }^{38}$ Ezra Tari and Talizaro Tafonao, "Pendidikan Anak Dalam Keluarga Berdasarkan Kolose 3:21," Kurios: Jurnal Teologi dan Pendidikan Agama Kristen 5, no. 1 (2019): 27.

${ }^{39}$ Manurung and Tafonao, "Problem Pembelajaran Online Di Masa Pandemi Terhadap Psikologi Anak Usia 10-12 Tahun." 
mendidik anak dari aspek motorik maupun hubungan interaksi antara orang tua dan anak dalam bekerja sama untuk melakukan tindakan secara berulang-ulang, jadi orang tua bisa menyiapkan loose part. Loose Part merupakan bahan-bahan terbuka yang mudah ditemukan di alam terbuka dan kehidupan sehari-hari yang dapat dipisah, namun bisa di satukan kembali, bisa dibawa, digabungkan, dijajarkan maupun dipindahkan. (Sinau Teacher Development Center ). ${ }^{40}$ Dengan metode pembelajaran ini (loose part) ini orang tua tidak perlu mengeluarkan banyak uang hanya untuk membeli mainan pabrik yang harganya mahal sebagai sarana anak-anak untuk bermain memanfaatkan barang-barang yang ramah lingkungan yang ada untuk bermain Anak usia dini merupakan pribadi yang unik serta memiliki kecerdasan naturalistik bawaan. Ada banyak potensi pada anak usia dini yang perlu dikembangkan mencakup seluruh aspek kemampuan dasar yakni aspek fisik motorik, aspek Bahasa serta nilai agama dan moral. Anak usia dini memiliki minat yang kuat mengulangi beberapa tindakan dalam waktu relatif lama terhadap objek yang diminati oleh anak usia dini, masa usia anak dini bisa dikatakan masa sensitif dimana masa sensitif itu meliputi mengeksplorasi lingkungan dengan lidah dan tangan, berjalan, keteraturan lingkungan, detail dari aspek-aspek sosial kehidupan dan objek-objek kecil.

Dengan situasi sekarang dan melihat kondisi keistimewaan yang dimiliki anak usia dini tersebut maka proses pembelajaran loose part sangat membantu para orang tua dirumah untuk dilakukan. Dengan metode loose part ini sesuai teks Ul. 6:7 bisa membantu anak usia dini memiliki minat mengulangi beberapa tindakan yang mereka minati, orang tua bisa mengajak anak bermain di rumah dengan memanfaatkan segala lingkungan sebagai tempat untuk belajar bagi anak agar anak-anak mudah mengerti apa yang sedang disampaikan. Seperti menghidangkan minuman pada media tertentu dan penyajian yang baik akan membantu anak belajar menghargai suatu barang, ciptaan Tuhan dan orang lain.

\section{KESIMPULAN}

Setelah membahas tentang mengembalikan pendidikan berpusat dari rumah selama pandemi, maka Pendidikan Agama Kristen dalam keluarga Kristen sangat penting untuk diulang-ulang untuk diajarkan ke anak-anak, karena Pendidikan Agama pada anak usia dini merupakan pondasi dalam pengenalan akan Firman Tuhan. Tujuan dari pengajaran tersebut yaitu agar orang tua dapat mengerti akan tanggung jawab mereka sebagai orang tua untuk mendidik anak-anak sesuai perintah Tuhan. Karena tanggung jawab orang tua adalah mendidik dan mengajar anak-anak akan nilai-nilai dalam hidup yang baik atau buruk. Sebab

${ }^{40}$ Nurani, 264.

218 | Copyright@ 2021, CARAKA, ISSN 2722-1407 (Cetak), 2722-1393 (Online) 
pendidikan pertama untuk anak bukanlah lembaga formal yang didatangi untuk menuntut ilmu, melainkan adalah rumah dimana mereka tinggal, tidak adalah alasan dimasa pendemi ini untuk tidak bisa mendidik anak karena berani mempunyai anak harus berani bertanggung jawab.

Berdasarkan kajian dalam artikel ini maka sebagai kesimpulan adalah mendidik dan mengajar anak-anak selama pandemi merupakan tanggung jawab orang tua berdasarkan tuntutan dari pemerintah serta prinsip-prinsip kebenaran yang terkandung didalam Alkitab sebagaimana penjelasan dalam artikel ini. Tulisan ini merupakan kajian baru dalam menanggapi berbagai probleman tentang pelaksanaan pembelajaran Anak Usia Dini selama pandemi dan kajian ini menjadi kontribusi bagi orang tua dalam mendidik anak-anak selama pandemi serta kepada peneliti berikutnya.

\section{DAFTAR PUSTAKA}

Albertz, Rainer, and Rudiger Schmitt. Family and Household Religion in Ancient Israel and the Levant. Winona Lake: Eisenbrauns, 2012.

Astuti, Isti Yuli, and Harun Harun. "Tantangan Guru Dan Orang Tua Dalam Kegiatan Belajar Dari Rumah Anak Usia Dini Pada Masa Pandemi Covid-19." Jurnal Obsesi : Jurnal Pendidikan Anak Usia Dini 5, no. 2 (2020): 1454-1463.

Darianti, and Talizaro Tafonao. "Problem Pembelajaran Pendidikan Agama Kristen Dimasa Pandemi Terhadap Psikologi Anak." SANCTUM DOMINE: Jurnal Teologi 10, no. 2 (2021): 39-56.

Donnalo, Reni Sandy. "Implementasi Pendidikan Dalam Ulangan 6:1-9 Kepada Anak Sekolah Minggu Kelas Besar Dengan Menggunakan Metode Role Play.” IAKN Toraja 2, no. 1 (2020): 1-8.

Dowansiba, Agustina. "Prinsip-Prinsip Mendidik Anak Usia 0-12 Tahun Berdasarkan Ulangan 6:1-9." LOGON ZOES: Jurnal Teologi, Sosial dan Budaya 1, no. 2 (2018): 94-112.

Grace, Adewumi Moradeke, Olojo Oludare Jetro, and Falemu Funke Aine. "Roles of Parent On The Academic Performance Of Pupils IIn Elementary Schools.” international journal pf academic Research in business and Social Sciences 2, no. 1 (2021): 180-190.

Hairuddin. "Pendidikan Itu Berawal Dari Rumah.” Jurnal Irfani 10, no. 1 (2014): 75-91. Harefa, Desy. "Kontribusi Pendidikan Kristen Bagi Pembentukan Rohani Dan Perilaku Anak Usia Dini." Real Didache: Jurnal Teologi Dan Pendidikan Agama Kristen 4, no. 2 (2019): 113-120.

Hartono, Handreas. "Membentuk Karakter Kristen Pada Anak Keluarga Kristen." Kurios 2, no. 1 (2018): 62-100.

Indrawan, Irjus, and Hadion Wijoyo. PENDIDIKAN ANAK PRA SEKOLAH. Edited by Abdul Rahmat. Vol. 1. Jawa Tengah: CV. Pena Persada, 2020.

Jane Gresia Akollo, Meike Elsa Toisuta. "Keterlibatan Orang Tua Dalam Pembelajaran Anak Usia Dini Selama Belajar Dari Rumah Di Masa Pandemi Covid-19.” INSTITUTIO: Jurnal Pendidikan Agama Kristen 6, no. 2 (2020): 64-74.

Kenny, James, and Mary Kenny. Dari Bayi Sampai Dewasa. Jakarta: BPK Gunung Mulia, 
1988.

Lasor, WS. Pengantar Perjanjian Lama. Jakarta: BPK Penabur, 1985.

Manurung, Rismag Dalena Florentina Monika Br, and Talizaro Tafonao. "Problem

Pembelajaran Online Di Masa Pandemi Terhadap Psikologi Anak Usia 10-12 Tahun.”

Mathetheou: Religios Studies 1, no. 1 (2021): 20-28.

Marisi, Candra Gunawan, Didimus Sutanto, and Ardianto Lahagu. "Keluarga Sebagai Pusat

Misi Masa Kini.” In Konfrensi Keluarga Kristen - The Great Commission, 1:77-91.

Batam: STT REAL BATAM, 2020.

Marsunu, Y. M. Seto. "Pendidikan Iman Anak Dalam Perjanjian Lama Dan Tradisi Yahudi,”."

Wacana Biblika 13, no. 4 (2013): 140-150.

Mufaziah, Eva, and Pujiyanti Fauziah. "Kendala Orang Tua Dalam Mendidik Anak Usia Dini

Pada Saat Pandemi Covid 19." Jurnal Obsesi : Jurnal Pendidikan Anak Usia Dini 5, no.

2 (2020): 1045-1051.

Nurani, Yuliani. Perspektif Baru Konsep Dasar Pendidikan Anak Usia Dini. Jakarta: CV.

CAMPUSTAKA, 2019.

Nursapiah. PENELITIAN KUALITATIF. Medan: Wal Ashri Publising, 2020.

Robert, R. Boehlke. Sejarah Perkembangan Pikiran Dan Praktek Pendidikan Agama Kristen.

Jakarta: BPK Gunung Mulia, 2009.

Sanjaya, V. Indra. "Hormatilah Ayahmu Dan Ibumu: Penghormatan Terhadap Orangtua

Dalam Perspektif 'Perintah Utama.” Wacana Biblika 13, no. 2 (2013): 54.

_. "Pendidikan Iman: Belajar Dari Tradisi Kuno." Wacana Biblika 9, no. 1 (2009): 310.

Tafonao, Talizaro. "Peran Guru Agama Kristen Dalam Membangun Karakter Siswa Di Era

Digital.” Journal BIJAK Basileia Indonesian Journal of Kadesi 2, no. 1 (2018): 1-37.

__. "Peran Pendidikan Agama Kristen Dalam Keluarga Terhadap Perilaku Anak."

Edudikara: Jurnal Pendidikan dan Pembelajaran, Vol 3 (2), 2018 ISSN 2541-0261 3, no.

2 (2018): 121-133.

Tari, Ezra, and Talizaro Tafonao. "Pendidikan Anak Dalam Keluarga Berdasarkan Kolose

3:21.” Kurios: Jurnal Teologi dan Pendidikan Agama Kristen 5, no. 1 (2019): 24-35.

Tety, Tety, and Soeparwata Wiraatmadja. "Prinsip-Prinsip Filsafat Pendidikan Kristen."

Evangelikal: Jurnal Teologi Injili dan Pembinaan Warga Jemaat 1, no. 1 (2017): 55-80.

U, Toseeb, Pickles A, Durkin K, Botting N, and Conti - Ramsden G. "Prosociality from Early

Adolescence to Young Adulthood: A Longitudinal Study Ofindividuals with a History of

Language Impairment. Research in Developmental Disabilities” 62 (2017): 148-159.

W, Santrock J. “Child Development.” New York: McGraw Hill Education (2014).

Wardani, Anita, and Yulia Ayriza. "Analisis Kendala Orang Tua Dalam Mendampingi Anak

Belajar Di Rumah Pada Masa Pandemi Covid-19." Jurnal Obsesi : Jurnal Pendidikan

Anak Usia Dini 5, no. 1 (2020): 772-782.

Wyclife. Tafsiran Alkitab. Malang: Gandum Mas, 2014.

"Https://Nasional.Kompas.Com/Read/2020/03/02/11265921/Breaking-News-Jokowi-

Umumkan-Dua-Orang-Di-Indonesia-Positif-Corona."

UNDANG-UNDANG REPUBLIK INDONESIA NOMOR 20 TAHUN 2003 SISTEM

PENDIDIKAN NASIONAL, 2003. 